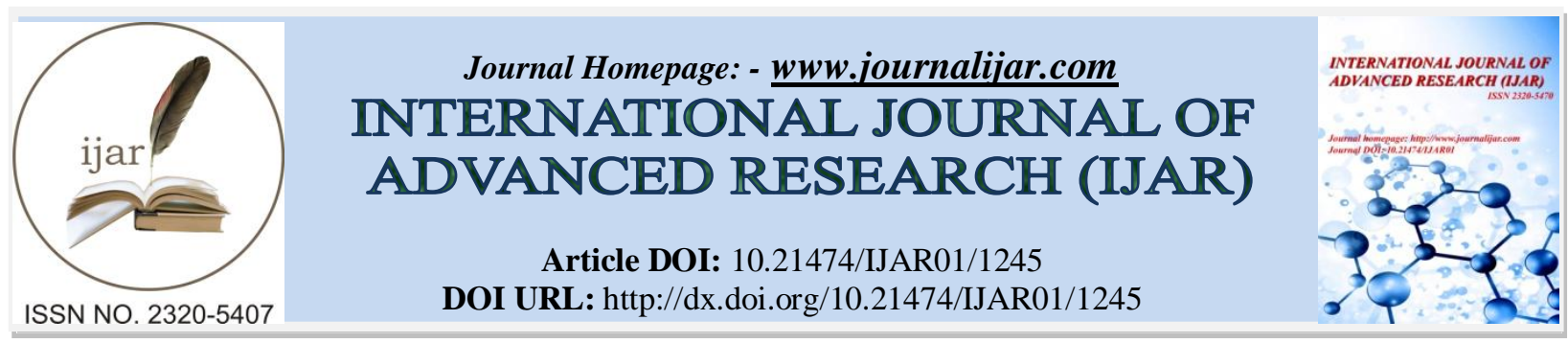

RESEARCH ARTICLE

\title{
INFLUENCE OF LADDER TRAINING ON BREATH HOLDING TIME AND HEART RATE AMONG KHO-KHO PLAYERS.
}

\author{
Dr. S. Sethu.
}

\section{Manuscript Info}

\section{Manuscript History}

Received: 12 June 2016

Final Accepted: 19 July 2016

Published: August 2016

Key words:-

\section{Abstract}

The purpose of the study was to find out to the effect of ladder training on breath holding time and heart rate among Kho-Kho players. To achieve the purpose of the study, twenty four $(n=24)$ Kho-Kho players were selected at random from Department of Physical Education and Sports, Manonmaniam Sundaranar University, Tirunelveli. The age of the selected subjects were between 21 to 25 years. The breath holding time and heart rate were selected as dependent variables and ladder training was selected as independent variables for this study. Breath holding time and heart rate was measured by using radial pulse and nostril hold methods respectively. A pre and post tests randomized design was employed for this investigation. The data was collected from the experimental and control groups before and after the experimental treatment. The analysis was carried out through various techniques such as the dependent t-test and the univariate analysis of covariance (ANCOVA). All of the statistical analysis tests were computed at 0.05 level of significance $(\mathrm{P}<0.05)$. It was concluded that, the experimental group namely ladder training group have achieved significant improvement on breathe holding time and heart rate when compared to the control group. It was also concluded that, significant differences were found between ladder training and control groups towards improving the breathe holding time and heart rate.

Copy Right, IJAR, 2016,. All rights reserved.

\section{Introduction:-}

One of the best things about running ladders is the specificity they provide instead of spending time in the pool or the weight room, ladders are a type of interval training that directly translates to better running performance. Even if you have no ambitions of running longer distances like a half-marathon or marathon and you're perfectly content with your pace, you might consider adding intervals to your routine. Intense interval training has been shown to increase not only speed but cardiovascular fitness and the body's ability to burn fat, even after returning to workouts of lower intensity (Andersson, J., \& Schagatay, E. 1998).

There is little or no research comparing the performance of athletes who do ladders-style workouts versus athletes who do straight, uniform-distance intervals. But there are distinct psychological benefits to completing intervals 
with varied lengths. Similarly, ladders can make an impossible distance seem surmountable. A fatigued athlete might find he can't complete the final mile of a run, but he can tack a ladders workout of the same length on to the end of a session and break the distance into several shorter intervals (Delistraty, D. A., Greene, W. A, Carlberg, K. A., \& Raver, K. K. 1991).

\section{Purpose of the Study:-}

The purpose of the study was to find out the effect of ladder training programme on breath holding time and heart rate among Kho-Kho players.

\section{Methodology:-}

To achieve the purpose of the study, twenty four $(n=24)$ Kho-Kho players were selected at random from Department of Physical Education and Sports, Manonmaniam Sundaranar University, Tirunelveli. The age of the selected subjects were between 21 to 25 years. The breath holding time and heart rate were selected as dependent variables and ladder training was selected as independent variables for this study. Breath holding time and heart rate was measured by using radial pulse and nostril hold methods respectively. A pre and post tests randomized design was employed for this investigation. The data was collected from the experimental and control groups before and after the experimental treatment. The analysis was carried out through various techniques such as the dependent t-test and the univariate analysis of covariance (ANCOVA). All of the statistical analysis tests were computed at 0.05 level of significance $(\mathrm{P}<0.05)$.

\section{Analysis of Data:-}

The effects of independent variables on selected criterion variables were determined through the collected data by using appropriate statistical techniques and the results are presented below. Mean values of experimental and control groups on selected variables were represented in figure.

Table i:- The summary of mean and Dependent ' $t$ ' test for the pre and post tests on selected physiological variables of ladder training and control groups.

\begin{tabular}{|c|c|c|c|}
\hline Variables & Mean \& t-test & Ladder Training Group & Control Group \\
\hline \multirow{3}{*}{ Breath Holding Time } & Pre test mean & 34.25 & 34.25 \\
\cline { 2 - 4 } & Post test mean & 48.91 & 35.33 \\
\cline { 2 - 4 } & 't' test & $4.92^{*}$ & 1.86 \\
\hline \multirow{2}{*}{ Heart Rate } & Pre Test Mean & 77.91 & 76.66 \\
\cline { 2 - 4 } & Post Test Mean & 72.08 & 76.66 \\
\cline { 2 - 4 } & 't' test & $3.29 *$ & 1.0 \\
\hline
\end{tabular}

$*$ Significant at 0.5 level. The table value required for 0.5 level of significant with df 11 is 2.20

Table ii:- Analysis of covariance on selected physiological variables of ladder training group and control group.

\begin{tabular}{|c|c|c|c|c|c|c|c|}
\hline \multirow[t]{2}{*}{ Variables } & \multicolumn{2}{|c|}{ Adjusted Post Test Mean } & \multirow{2}{*}{$\begin{array}{c}\text { Sources } \\
\text { of } \\
\text { Mean }\end{array}$} & \multirow{2}{*}{$\begin{array}{l}\text { Sum of } \\
\text { Square }\end{array}$} & \multirow[t]{2}{*}{ df } & \multirow{2}{*}{$\begin{array}{c}\text { Mean } \\
\text { Squares }\end{array}$} & \multirow[t]{2}{*}{ F-ratio } \\
\hline & $\begin{array}{l}\text { Ladder } \\
\text { Training }\end{array}$ & $\begin{array}{l}\text { Control } \\
\text { Group }\end{array}$ & & & & & \\
\hline \multirow{2}{*}{$\begin{array}{c}\text { Breath Holding } \\
\text { Time }\end{array}$} & \multirow[t]{2}{*}{48.92} & \multirow[t]{2}{*}{35.33} & Between & 1107.04 & 1 & 1107.04 & \multirow[t]{2}{*}{$20.88 *$} \\
\hline & & & Within & 1113.51 & 21 & 53.02 & \\
\hline \multirow[t]{2}{*}{ Heart Rate } & \multirow[t]{2}{*}{71.77} & \multirow[t]{2}{*}{76.98} & Between & 161.83 & 1 & 161.83 & \multirow[t]{2}{*}{$14.7 *$} \\
\hline & & & within & 231.22 & 21 & 11.01 & \\
\hline
\end{tabular}

*significance at 0.5 level of confidence. The table value required for significance at 0.5 level with df 1 and 21 is 4.32 . 


\section{Mean values of experimental and control groups on selected variables:-}

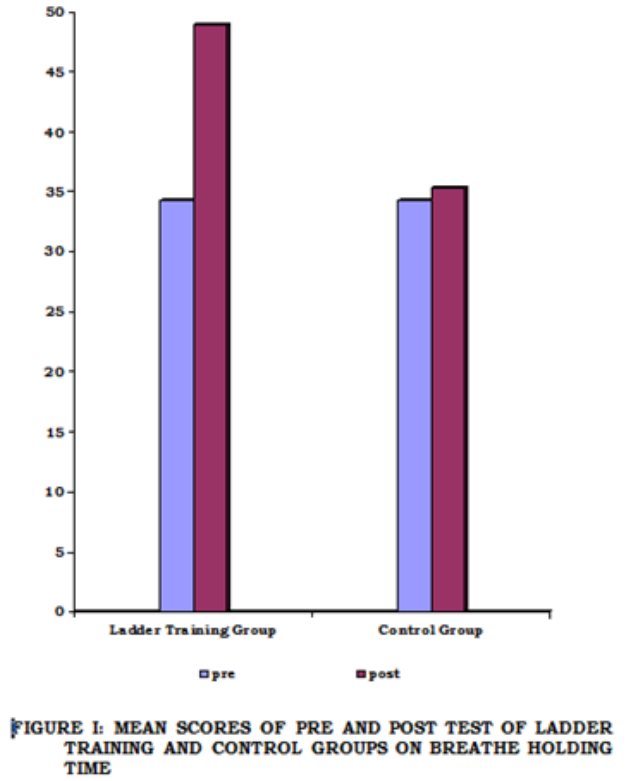
TIME

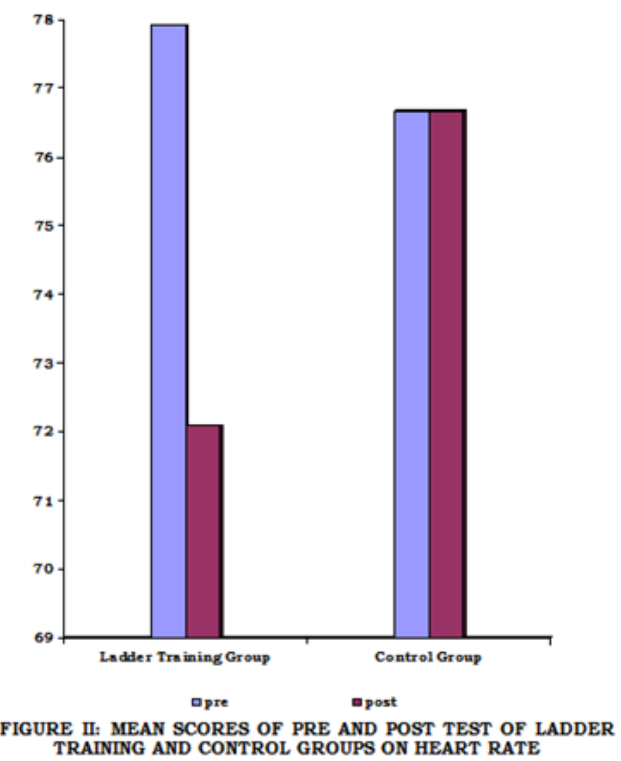

\section{Discussion on findings:-}

The result of the study indicated that the experimental group namely ladder training group have achieved significant improvement on breathe holding time and heart rate when compared to the control group.

It also indicated that, significant differences were found between ladder training and control groups towards improving the breathe holding time and heart rate. The result of the study was supported by many of the previous findings. The heart rate reduction is observed in our kho-kho players was similar to that of previous studies (Lemaitre, F., Bernier, F., Petit, I., Renard, N., Gardette, B., Joulia, F. 2005). In this study, the significant reduction in heart rate due to the effect of ladder training. This is similar to observation and comparison between training and competitions in other sports events McKay, J. M., Selig, S. E., Carlson, J. S, \& Morris, T. 1997).

In order to perform well, the athlete strives to be as relaxed as possible both prior to and during the critical situations of game. Mental stress has been shown to increase both heart rate and oxygen uptake and decreased breath holding time (Delistraty, D. A., Greene, W. A, Carlberg, K. A., \& Raver, K. K. 1991), although HR under mental stress appears to overestimate the oxygen uptake compared to the same HR during exercise (Seematter, G., Guenat, E., Schneiter, P, Cayeux, C., Jequier, E., \& Tappy, L. 2000). There are no quantitative data on oxygen consumption and heart rate, however it has been shown that the reduction in HR is related to a reduced desaturation rate in arterial oxygen saturation due to 12 weeks of resistance training (Andersson, J., \& Schagatay, E. 1998).

Kooyman and Campbell (1972) showed that initial heart rate in freely diving Weddell seals varied inversely with training duration up until $25 \mathrm{~min}$. In contrast, in our subjects anticipation of training appeared to counteract the initial heart rate reduction and maintain the heart rate at a higher level.

Kingwell, B. A., \& Jennings, G. L. (1993) suggested that training at 80-90\% of maximal work load was less effective than training at 65-70\%, but Braith, R. W., M. L. Pollock, D. T. Lowenthal, J. E. Graves, \& Limacher, M. C. (1994) observed similar net blood pressure reduction of about $8 \mathrm{~mm} \mathrm{Hg}$ when training at $70 \%$ and at $80-85 \%$ of heart rate reserve.

It is inferred from the literature and from the result of the present study. That systematically designed training develops dependent variables are very importance quilts for better performance in almost all sports and games. Hence it is concluded that systematically designed training may be given due recognition and implemented properly in the training programs of all the discipline in order to achieve maximum performance. 


\section{Conclusions:-}

From the analysis of the data, the following conclusions were drawn.

1. The experimental group namely ladder training group have achieved significant improvement on breathe holding time and heart rate when compared to the control group.

2. Significant differences were found between ladder training and control groups towards improving breathe holding time and heart rate.

\section{References:-}

1. Andersson, J., \& Schagatay, E. (1998). Arterial oxygen desaturation during apnea in humans. Undersea Hyperb Med 25: 21-25.

2. Andersson, J., Tomberg, P., \& Schagatay, E. (2000). Influence of volition on the human diving response. Undersea Hyperbaric Medical Society, Annual meeting, Undersea and Hyperbaric Medicine 27 (suppl).

3. Braith, R. W., M. L. Pollock, D. T. Lowenthal, J. E. Graves, \& Limacher, M. C. (1994). Moderate-, and highintensity exercise lowers blood pressure in normotensive subjects 60 to 79 years of age. Am. J. Cardiol. 73:1124 -1128 .

4. Delistraty, D. A., Greene, W. A, Carlberg, K. A., \& Raver, K. K. (1991). Use of graded exercise to evaluate physiological hyperreactivity to mental stress. Med Sci Sports Exercise, 23: 476-481.

5. Kingwell, B. A., \& Jennings, G. L. (1993). Effects of walking and other exercise programs upon blood pressure in normal subjects. Med. J. Aust. 158:234 -238.

6. Kooyman, G. L., \& Campbell, W. B. (1972). Heart rates in freely diving Weddell Seals, Leptonychotes weddelli. Comp Biochem Physiol A 43: 31-36.

7. Lemaitre, F., Bernier, F., Petit, I., Renard, N., Gardette, B., Joulia, F. (2005). Heart rate responses during a breath-holding competition in well-trained divers. International Journal of Sports Medicine, $26: 409$ 13

8. McKay, J. M., Selig, S. E., Carlson, J. S, \& Morris, T. (1997). Psychophysiological stress in elite golfers during practice and competition. Australian Journal of Science and Medicine in Sport, 29: 55-61.

9. Schagatay, E., Van Kampen, M., Emanuelsson, S., Holm, B. (2000). Effects of physical and apnea training on apneic time and the diving response in humans. European Journal of Applied Physiology, 82 : $161-9$

10. Seematter, G., Guenat, E., Schneiter, P, Cayeux, C., Jequier, E., \& Tappy, L. (2000). Effects of mental stress on insulin-mediated glucose metabolism and energy expenditure in lean and obese women. American Journal of Physiology and Endocrinology Metabolism, 279: E799-805. 